\title{
Estimating conservation effectiveness across protected areas in Limpopo Province, South Africa
}

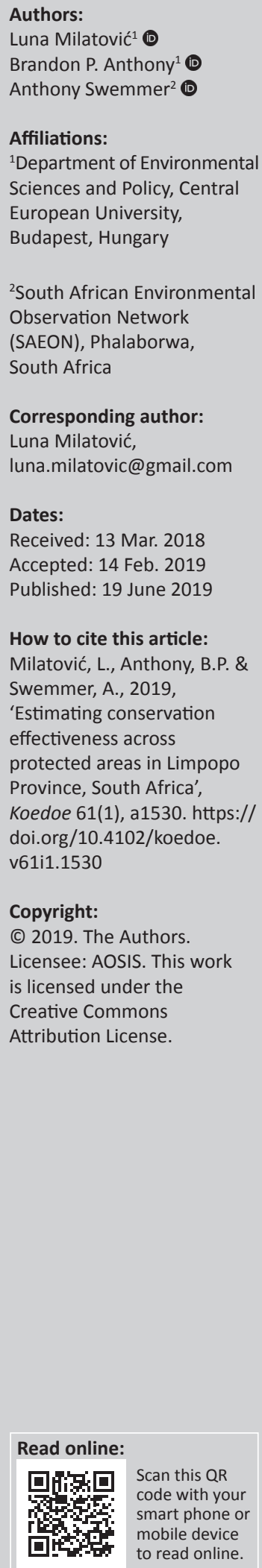

Protected areas (PAs) are considered the cornerstone of biodiversity conservation, and their establishment is often used to demonstrate the success of conservation policies. However, despite the increase in number and extent of PAs, global trends of biodiversity loss remain largely unchanged. It has become apparent that simply establishing a PA is not enough, and effective management is equally important for achieving conservation success. The importance of management monitoring and evaluation systems has been recognised by numerous institutions, triggering the development of various conservation performance assessment frameworks and tools, each varying in their accuracy, scale and application. Modified threat reduction assessment (MTRA) was selected to evaluate the management effectiveness of the Letaba Ranch Nature Reserve (LRNR), which serves as a buffer area of the Kruger National Park (KNP), South Africa, and two KNP sections bordering it (Mahlangeni and Phalaborwa). The aim of this research was to determine the nature of threats to biodiversity and their changes between 2013 and 2017 in all three sites. The research revealed 13 threats and determined negative MTRA indices of $-33.6 \%$ in the LRNR and $-14.7 \%$ in the Phalaborwa section, but a $13.2 \%$ reduction in threats in the Mahlangeni section. Combined with the results of geospatial visualisation of changes in threats, we suggest that the LRNR is not sufficiently meeting the objective of supporting the ecological integrity of the KNP, but further exposes it to threats, and that MTRAs can be useful for measuring and comparing threats across PA boundaries.

Conservation implications: South Africa has initiated a Strategy on Buffer Zones which seeks to buffer threats to national parks. Evaluating how well buffer reserves function in this capacity is crucial for understanding management effectiveness and resource allocation. Utilising a combination of MTRAs and geospatial tools can assist managers in understanding threats and their mitigation across PAs.

Keywords: protected areas; conservation success; management effectiveness; threat reduction assessment; biodiversity; buffer zone.

\section{Introduction}

As we enter what many scientists call the Earth's six mass extinction (McCallum 2015; Pimm et al. 2014; Thomas et al. 2004), the importance of biodiversity conservation is more apparent than ever. Declines in biodiversity are associated with changes that are reducing or homogenising biological diversity at many levels, from genes to habitats and ecosystems (Gaston \& Spicer 2004). Probably the most efficient and widespread tool developed in response to the biodiversity crisis is the establishment of protected areas (PAs). Today, there are 202467 designated terrestrial and inland water PAs, covering 14.7\% of the land surface (UNEP-WCMC \& IUCN 2016). However, despite the increased number and extent of the protected area (PA) portfolio over recent decades (Chape et al. 2005), biodiversity loss continues (Bertzky et al. 2012) and, in some cases, even within PAs (Craigie et al. 2010; Françoso et al. 2015; Laurance et al. 2012). This has led to the growing recognition that effective management of PAs is at least as important as their size, number and physical characteristics (IUCN-WCPA 2009; Leverington et al. 2010).

There is therefore a need for management effectiveness evaluation (MEE) which can assist PA management staff to assess their current management strategies, and identify shortcomings and successes, so they can modify interventions and allocate resources more efficiently (Salafsky \& Margoluis 1999). Monitoring is a crucial component of any evaluation needed for detecting changes and tracking progress towards management objectives (Tucker 2005). Protected Area Management Effectiveness (PAME) schemes were developed as a way of examining PA performance using management indicators (Hockings \& Phillips 1999) and gained momentum 
by the obligations for Convention on Biological Diversity signatory countries to achieve management effectiveness assessments for $60 \%$ of their PAs by 2015 (CBD 2010). Although there are many approaches and tools used to evaluate management effectiveness, no single PAME evaluation system is suitable for all PAs, and the aims and circumstances under which PAME is conducted are very diverse. In fact, there are more than 50 different MEE methodologies (Leverington et al. 2010), most of which are modified standard approaches adapted to specific local conditions (Hockings 2003). Threat reduction assessment (TRA), developed by Salafsky and Margoluis (1999), measures management effectiveness indirectly by concentrating on changes in direct biodiversity threats within a PA. Threat reduction assessment is particularly useful where little or no baseline data exist on biodiversity, and when comparing this across sites, it yields a more focused and detailed approach on direct threats to biodiversity and conservation than other widely used MEE tools. It is used to measure outcomes and identify effective management strategies, while overcoming the limitations of using biological indicators (Salafsky \& Margoluis 1999). The tool was later modified (modified threat reduction assessment [MTRA]) to assess changes in threats more accurately by allowing for the inclusion of worsening or emerging threats a recognised deficiency in the original tool (Anthony 2008).

\section{Republic of South Africa}

The Republic of South Africa (RSA) covers a total land surface area of $1221037 \mathrm{~km}^{2}$ (UN 2017) and is listed by Conservation International as one of the 17 megadiverse countries of the world, because of its highly diverse ecosystems, species richness and endemism (Driver et al. 2011). However, its biodiversity is under increasing pressure because of inter alia loss and degradation of natural habitats, overexploitation of natural resources (including poaching) and invasive alien species (IAS) (Driver et al. 2011).

The Republic of South Africa has a number of national policies and legislative frameworks addressing conservation and management of natural resources and biodiversity. The National Environmental Management: Protected Areas Act of 2004 (NEM: PAA) is the main legislative document concerning the protection of the RSA's biodiversity and conservation, while the National Biodiversity Framework (DEAT 2009) serves to align conservation efforts across institutions. Another important aspect of PAs in RSA is the recently legally recognised concept of buffer zones around PAs, outlined in the Biodiversity Policy and Strategy for South Africa: Strategy on Buffer Zones for National Parks (Notice 106 of 2012). Globally, the concept originated by a growing realisation that PAs cannot be managed as static, isolated islands, but are often subsets of larger ecosystems (Hansen et al. 2011), and that the long-term conservation success of PAs can be enhanced only when socio-ecological relationships with the surrounding landscape are considered (Bengtsson et al. 2003; Palomo et al. 2014). This includes a heightened appreciation of effective reserve sizes, ecological flows in and out of PAs, crucial habitats as well as negative edge effects from PA peripheries (Hansen \& DeFries 2007). Buffer zones gained momentum as a conservation tool in the 1970s through UNESCO's Man and Biosphere Programme (UNESCO 1974), which introduced the zoning hierarchy of buffer areas: the first layer of protection around the core area is the buffer zone which is surrounded by a transition area, where a greater level of land use is allowed. The principal idea is to safeguard areas that have biodiversity conservation as their primary objective (core areas) from harmful external impacts, while allowing a certain level of sustainable human activities that are consistent with the protection of the core area. This is particularly relevant for RSA's PAs, many of which are located in densely populated and impoverished parts of the country. The Strategy on Buffer Zones for National Parks, adopted in 2012, outlines a clear mission 'to best protect the integrity of national parks, their purpose and values while enabling sustainable benefits to those persons and communities living next to the national parks'. Therefore, the strategy presents not only an invaluable contribution to the protection of PAs but also a tool for increased inclusion of the local community. There are a number of different forms of buffer zones, all with somewhat different objectives, including the so-called buffer parks around the Kruger National Park (KNP). This mosaic of buffer areas around the KNP, and how they contribute to ecosystem resilience, can only be better understood when both governance structures and broader socio-ecological processes are considered together in monitoring and management (Cumming and Allen 2017; Cumming et al. 2015).

Although previous studies have explored large-scale, satellite-based land use transformations just south of our study area (Coetzer et al. 2013), and threat mitigation by the KNP and Limpopo Province to the north (Anthony 2008), our study is the first to compare finer scale threats across adjacent PAs with differing governance structures in the region.

\section{Methodology Study area Kruger National Park}

The Kruger National Park (KNP) covers approximately $20000 \mathrm{~km}^{2}$ in the north-eastern part of RSA and attracts over 1 million visitors annually. The Kruger National Park's biodiversity is significant because of its size, distinctive landscapes and geological diversity (SANParks 2018). One of the key features of the KNP is its protection of 150 mammal species (SANParks 2018), including many of the Earth's remaining megafauna populations (Ripple et al. 2016).

The park is divided into 22 sections, each managed under a common KNP Management Plan. Owing to their location, the Phalaborwa and Mahlangeni sections were selected for this study (Figure 1). The Mahlangeni section covers an area of approximately $1160 \mathrm{~km}^{2}$ of mopane-dominated woodlands on granite (Gertenbach 1983), whereas the Phalaborwa section is slightly smaller, covering $1035 \mathrm{~km}^{2}$ of similar vegetation (Gertenbach 1983). One of the park's entry gates (Phalaborwa) is located in this section. 


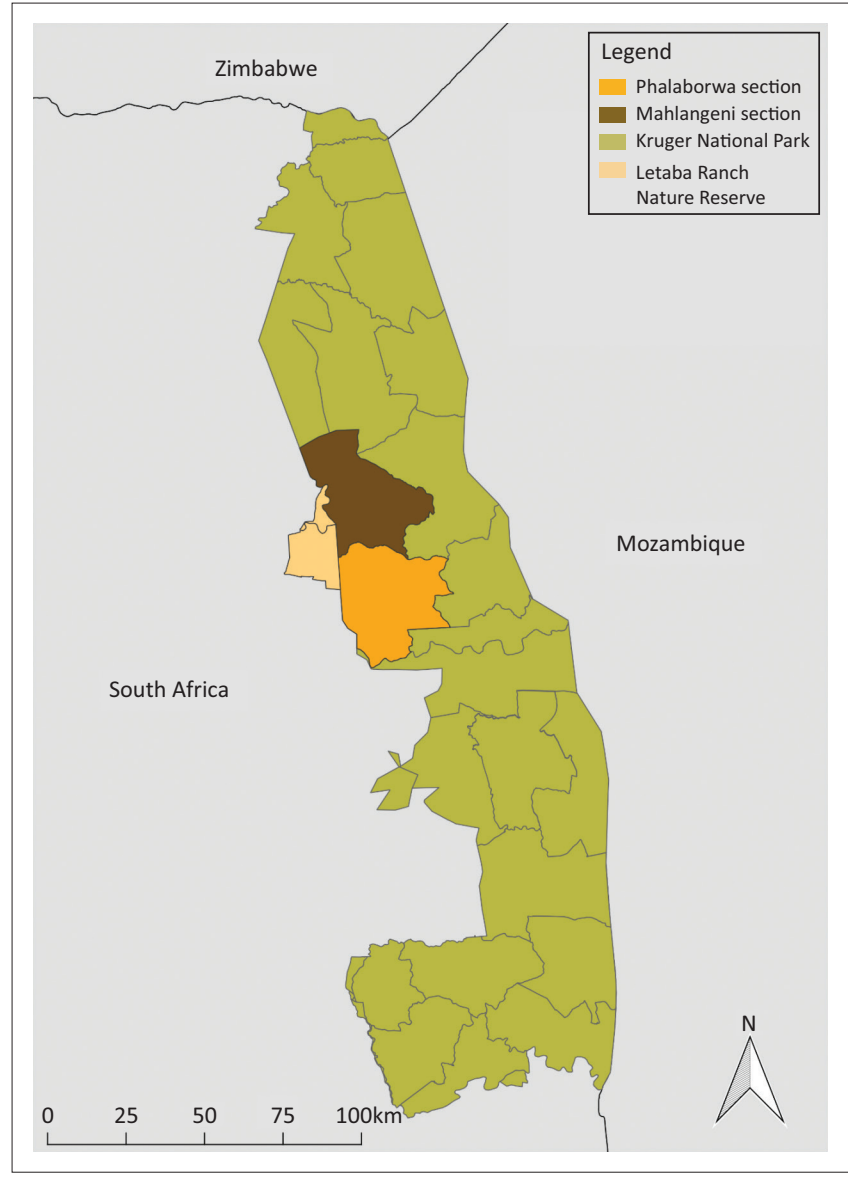

$\mathrm{km}$, kilometres.

FIGURE 1: Location of study areas.

\section{Letaba Ranch Nature Reserve}

The Letaba Ranch Nature Reserve (LRNR) is a provincial nature reserve located in the Ba-Phalaborwa and Greater Giyani municipalities of the Mopani district in the Limpopo Province, covering an area of $420 \mathrm{~km}^{2}$. It is positioned along the western boundary of the KNP, north of the Phalaborwa Gate, and serves as a buffer between the park and settlements and agricultural areas to the west. Fences between the LRNR and the KNP were dismantled in 2006 (Swemmer \& Mmethi 2016), allowing the free movement of fauna between the PAs. Under the most recent management plan (LEDET 2013), a number of management issues have been highlighted inter alia susceptibility to drought, unsustainable hunting and invasive species control. The Mthimkhulu Nature Reserve (MNR), a community-owned nature reserve of $63.49 \mathrm{~km}^{2}$ bordering the LRNR to the north, is managed by the same provincial authority (LEDET 2013) under the same management plan and is thus treated as part of the LRNR here.

\section{Modified threat reduction assessment tool}

To evaluate management effectiveness in the selected sites, it was important to utilise a suitable PAME tool. Modified threat reduction assessment was chosen as it allows for comparison between sites, does not require previously collected baseline data, is relatively easy to apply, facilitates management monitoring without highly trained staff and is cost-effective (Anthony 2008; Salafsky \& Margoluis 1999). Previously conducted MTRAs have identified group discussions as the most effective way of applying the tool, with a workshop style being particularly fitting (Anthony 2008; Matar \& Anthony 2010). The Kruger National Park section rangers and the LRNR managers were invited to participate and were provided with information on criteria for workshop participant selection, that is, experience working in the area during the entire assessment period; intimate knowledge of the site; and familiarity with concepts such as biodiversity, habitat conditions and ecosystem services.

Three workshops were conducted: two in the Mahlangeni and Phalaborwa sections of the KNP, and one in the LRNR. Each workshop commenced with a presentation introducing the methodology, key concepts and definitions, as well as a step-by-step explanation of the workshop. The MTRA assessed the area of $5 \mathrm{~km}$ from the border inside the Mahlangeni and Phalaborwa sections of the KNP (assumed by workshop participants to adequately account for border effects) and the whole of the LRNR. The assessment period was selected to be from 2013, the year the LRNR adopted its 5-year Strategic Plan (LEDET 2013), until present (May 2017). The same timeframe was used for the KNP to allow for comparison. Utilising the IUCN Standard Lexicon of Threats (Salafsky et al. 2008), participants were instructed to identify and list direct threats present at the beginning of the assessment period in their area and any emerging threats over the assessment period. After developing the final list, the top ten threats were chosen and categorised according to the IUCN lexicon. Participants were asked to describe the specifics of the identified threats in their area to minimise the possible loss of information resulting from threat standardisation (Anthony 2008) and consulting the lexicon if required. Participants were then asked to agree on detailed definitions of the identified threats and determine what a $100 \%$ reduction of that threat would be. The moderator defined a $100 \%$ threat reduction 'as complete eradication of a given threat', following Anthony (2008), who notes that any other definition may cause ambiguity. However, if participants recognised that total threat elimination is not feasible, a different definition of $100 \%$ reduction was made. The participants were then asked to rank each threat in regard to its area, intensity and urgency. The scoring scale was defined depending on the number of identified threats, with number 1 being the minimum score without the possibility of equal scoring. Participants were advised in advance to consult any reports to minimise subjectivity and increase validity of the method. Criteria scores were summed to calculate a 'total ranking' for each individual threat. Participants were then asked to review the rankings and decide if this is the true representation of the threats in their area, allowing them to modify their rankings and increase the legitimacy of the results. Participants were then given time to independently estimate (as a percentage) to what degree the threat had increased or decreased over the assessment period. After group discussion, they corporately decided on the final percentage for each threat (Anthony 2008). If the threat had 
been mitigated, they gave a positive score, with the top score being $+100 \%$ if the threat had been eliminated. If a threat had worsened since the start date, the score was negative and had no lower bound. If a threat was absent at the assessment start date, but emerged since then, that threat was given a score of $-100 \%$. Dividing the sum of the raw scores for each threat by the total possible rankings of all the threats and multiplying by 100 computed the threat reduction index:

$($ MTRAindex $=\Sigma$ Total raw scores $/ \Sigma$ Total rankings $\times 100) \quad[$ Eqn 1$]$

The second part of the workshop focused on the spatial demarcation of threats. Geospatial data collection was carried out following Anderson (2012). Management teams were given two blank site maps and instructed to collectively draw the approximate location of threats identified during the MTRA. After discussing each threat and deciding on its approximate location, threats at the beginning (2013) and end (2017) of the assessment period were drawn on separate maps to avoid overlapping and confusion during data analysis. To orientate themselves and substantiate the method, participants consulted their daily ranger patrol maps. Maps produced during the MTRA workshops were digitised and analysed in ArcGIS 10.2. Each threat was constructed as a separate layer and then merged to produce final maps. In total, two maps displaying the spatial arrangement of threats to biodiversity were produced across all sites, that is, the start and end of the assessment period.

All information was collated by the moderator and projected on the wall during the workshop to increase workshop coherence. At the end of each workshop, there was an informal discussion concerning the nature of the threats identified, management interventions and how successful or unsuccessful management teams had been in their mitigation.

\section{Ethical considerations}

This research was approved by, and adhered to, the Central European University, Research Ethics Policy and Guidelines.

\section{Results}

A total of 28 participants contributed to the MTRA workshops (8, 12 and 8 in Mahlangeni, Phalaborwa and the LRNR, respectively). The majority of participants were field rangers; however, section rangers from Mahlangeni and the LRNR also participated. In total, 13 threats were identified across the three sites (Table 1), with 'hunting and collection of terrestrial animals' and 'invasive alien species' present across all study sites, 'fire and fire suppression' and 'utility and service lines' were restricted to the KNP only, and six threats isolated to one site only.

\section{Letaba Ranch Nature Reserve}

The reserve management team identified 10 major threats to the reserve's biodiversity (Table 1-A1). The MTRA index of $-33.6 \%$ indicated that total threats had worsened since 2013.
TABLE 1: Identified threats to biodiversity and percent mitigation from 2013 to 2017 in the Letaba Ranch Nature Reserve, and Mahlangeni and Phalaborwa sections of the Kruger National Park.

\begin{tabular}{|c|c|c|c|c|c|}
\hline \multirow{2}{*}{$\begin{array}{l}\text { IUCN } \\
\text { code }\end{array}$} & \multirow[t]{2}{*}{ Threat } & \multirow{2}{*}{$\begin{array}{l}\text { LRNR } \\
(\%)\end{array}$} & \multicolumn{2}{|c|}{ KNP (\%) } & \multirow[t]{2}{*}{ Total sites } \\
\hline & & & Mahlangeni & Phalaborwa & \\
\hline 5.1 . & $\begin{array}{l}\text { Hunting and collection } \\
\text { of terrestrial animals }\end{array}$ & +5 & +49 & +60 & 3 \\
\hline 8.1. & Invasive alien species & +50 & +70 & -200 & 3 \\
\hline 7.1 . & Fire and fire suppression & na & +30 & +80 & 2 (only KNP) \\
\hline 4.2 . & Utility and service lines & na & 0 & 0 & 2 (only KNP) \\
\hline 9.4. & Garbage and solid waste & -40 & -10 & na & 2 \\
\hline 5.4. & (Illegal) Fishing & 0 & -50 & na & 2 \\
\hline 3.2 . & Mining & -100 & -50 & na & 2 \\
\hline 11.2. & Drought & -110 & na & na & 1 \\
\hline 5.3. & Wood harvesting & +50 & na & na & 1 \\
\hline 8.2 . & $\begin{array}{l}\text { Problematic native } \\
\text { species }\end{array}$ & -200 & na & na & 1 \\
\hline 9.3. & Agricultural effluents & -70 & na & na & 1 \\
\hline 7.2 & Dams & 0 & na & na & 1 \\
\hline 9.5 . & Air pollution & na & na & 0 & 1 \\
\hline $\begin{array}{l}\text { Total } \\
\text { threats }\end{array}$ & 13 & 10 & 7 & 5 & 22 \\
\hline
\end{tabular}

na, threat not identified; IUCN, International Union for the Conservation of Nature; LRNR, Letaba Ranch Nature Reserve; KNP, Kruger National Park.

This was largely because of two newly emerged threats, '(sand) mining' and 'drought', which were given a score of $-100 \%$ accordingly (Figure $2 b$ ). The threat of 'problematic native species' had doubled since 2013, which contributed heavily to the negative overall index. Despite a reduction of 5\%, (mostly illegal) 'hunting' was recognised as the top threat, followed by 'drought' and 'fishing', the latter remaining unchanged according to the management team. The threats of 'invasive alien species' and 'wood harvesting' had both halved, while pollution from 'agricultural effluents' from surrounding crop land and 'garbage and solid waste' had worsened. Rangers also recognised 'dams' and 'illegal fishing' in the reserve as threats, but identified no change during the assessment period.

\section{Mahlangeni}

There was a moderate improvement of $13.2 \%$ in the MTRA index for Mahlangeni, as a result of the reduction of three of seven identified threats (Table 2-A1; Figure 2b). Despite considerable reduction $(+49 \%)$, 'hunting' still emerged as the top threat, followed by 'fishing' that had worsened (-50\%), and 'invasive alien species' that had been significantly mitigated (+70\%). 'Mining' and 'garbage and solid waste' were both identified as worsening threats, originating from outside the park. Lastly, 'utility and service lines' within the $\mathrm{KNP}$ were not perceived as a serious problem, and the impact of their threat remained constant.

\section{Phalaborwa}

Management staff identified five threats (Table 3-A1; Figure 2a). 'Hunting' and 'fire' had declined; however 'hunting' remained the top threat in 2017 in terms of the area affected, intensity and urgency. 'Air pollution' from a nearby mine remained the same, as did the threat of 'utility and service lines'. On the contrary, the problem of 'invasive alien species' had worsened and was given a score of $-200 \%$, which 


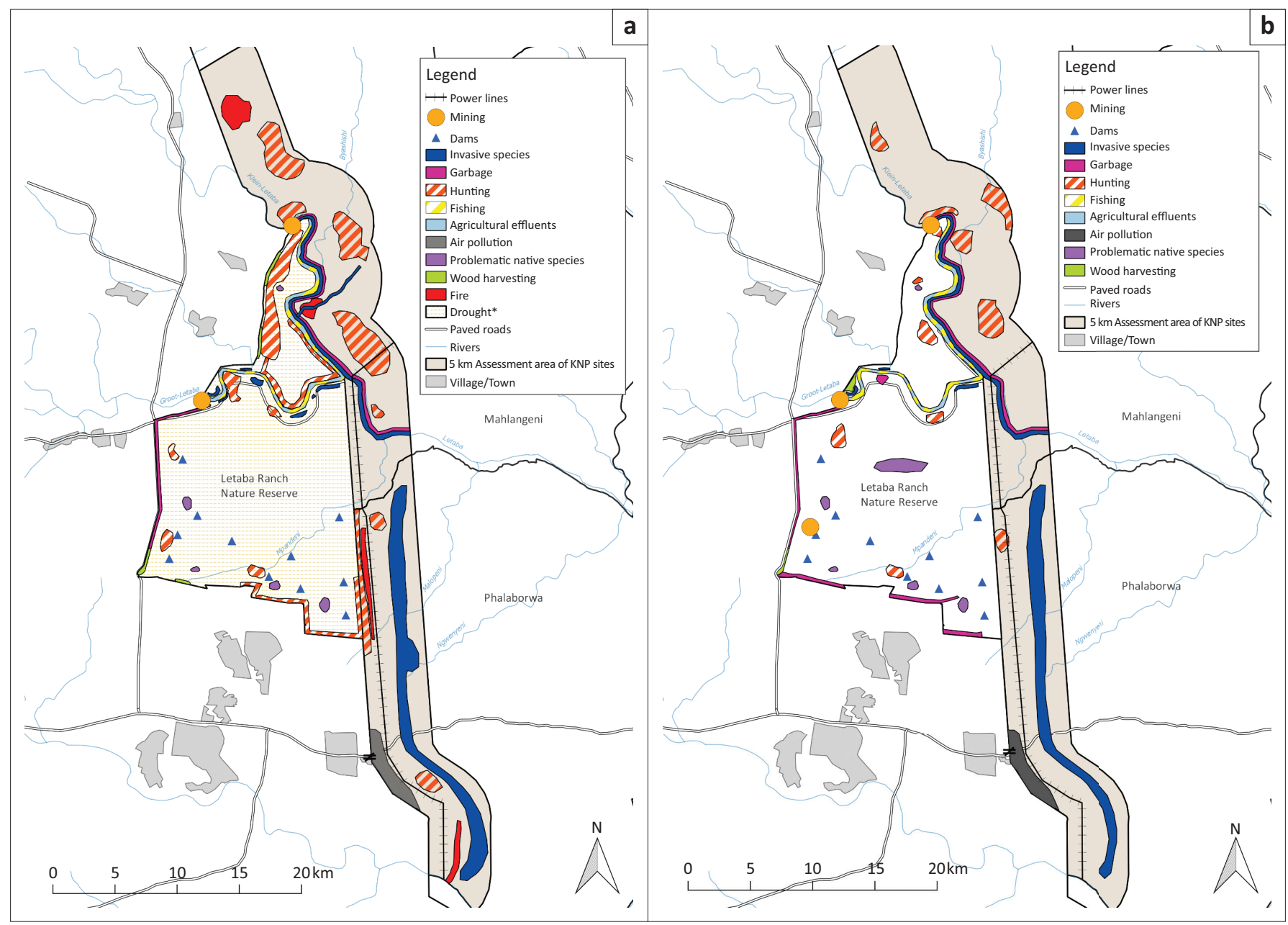

Note: Drought was not present in 2013, but in 2014. However, the LRNR management team wanted it illustrated to indicate the spatial scale of the threat. FIGURE 2: Spatial demarcation of threats to biodiversity in assessed areas in (a) 2013 and (b) 2017.

was primarily responsible for the negative overall MTRA index of $-14.67 \%$.

\section{Discussion}

\section{Knowledge gained (threats and drivers)}

A number of threats that were identified in more than one site (Table 1) and their spatial organisation, as delineated from the threat maps, provide insights into their source(s) and reasons for change. Although our study identified a total of 13 threats, we focus on five categorical threats common across at least two sites, which we believe are functionally linked.

Hunting and collection of terrestrial animals was recognised in all three sites as the top threat. In the LRNR, the management team expressed concern about poaching, commercial hunting activities and hunting quotas given to neighbouring communities. Poaching was identified as the dominant threat in the reserve, and it was alleged that this illegal activity is usually carried out by people living adjacent to the reserve, who hunt for bushmeat as a source of food or as a source of income. Most of the subsistence poaching is carried out using snares, targeting impala (Aepyceros melampus), kudu (Tragelaphus strepsiceros) and buffalo (Syncerus caffer). A select group of poachers target elephants (Loxodonta africana) and rhinos (Ceratotherium simum simum) which move freely into the reserve from the KNP. Apart from poaching, hunting quotas given to the communities present a threat as they are purportedly not scientific estimates of sustainable levels of offtakes, an issue previously identified as a challenge in the LRNR Strategic Plan (LEDET 2013). Irregularities concerning issuing of these quotas and hunting rights have been investigated by the Letaba Herald (2015), a local newspaper and EMS Foundation (2016), which published its findings in a report prepared for CITES CoP 2017. Both sources list individuals being involved with reselling of hunting rights in a network underpinned by corruption in the reserve. No official statements regarding the issue were made by the Limpopo Department of Economic Development, Environment and Tourism (LEDET), and these claims are based on grey information. However, it is important to keep this in mind to understand the context in which the reserve is being managed. Commercial hunting in the reserve, which was previously common, ceased in 2015, but is likely to resume according to workshop participants. The light reduction in the threat of poaching was ascribed to the increased frequency of patrols by the rangers.

In Mahlangeni, poaching for bushmeat, ivory, rhino horns and vulture poisoning was identified, as well as illegal 
harvesting of mopani caterpillars (Imbrasia belina). Rangers from the Phalaborwa section identified rhino poaching as the dominant threat, while there was a concern that poaching for ivory would likely become the prevailing threat in the future. In addition to anti-poaching measures, the reduction of the threat in both sections can be explained by the fact that there are far fewer rhinos in the area than in 2013. According to both management teams, the number of poachers recorded in the area decreased in accordance with a decline in rhino numbers. The threat maps illustrate a potential pattern that could help understand poachers' entrance points into the KNP. In Mahlangeni, areas in which poaching incidents were recorded are prevalent in the southern portion of the assessed area, which borders the northern half of the LRNR (Figure 2a, b). Similarly, the Phalaborwa management team identified a high-intensity poaching zone in the far north of the section, which borders the southern half of the LRNR (Figure 2a, b). The Letaba Ranch Nature Reserve therefore appears to function as a gateway for poachers into the KNP, rather than a buffer that restricts the movement of poachers. This reflects the widely held perception of poor management practices and law enforcement within the LRNR.

Invasive alien species was also recognised in all three sites as one of the top four threats, with the situation improving in the LRNR and Mahlangeni since 2013 but deteriorating in Phalaborwa. In Mahlangeni, invasive alien plants occur primarily along the Letaba River which flows between the two sections. Periodic flooding of this river results in frequent colonisation of exposed river banks for a variety of alien plant species. While the Phalaborwa section also borders this river, rangers were more concerned with Indian myna (Acridotheres tristis) and large patches of alien vegetation that have emerged in terrestrial areas since 2013, contributing to the doubling of this threat for this section. Rangers ascribed the $-200 \%$ worsening of IAS to staff shortages in the section, claiming that there are not enough people to regularly clear alien plants. In the LRNR, the extent and intensity of IAS invasion are not as well researched as in the KNP, but there are several known patches along the Groot Letaba River (Figure 2a, b). In Mahlangeni, rangers attributed the $70 \%$ reduction in the IAS threat to successful control completed in the same manner as in the LRNR, on an ad hoc basis (LEDET 2013). However, the threat map for Mahlangeni did not reflect this, with only a minimal decrease in area in 2017 compared to 2013 but with continued urgency and intensity of the problem (Figure 2b).

The geospatial data for fishing indicated that illegal fishing in Mahlangeni only takes place on the western side of the section, again suggesting that the LRNR acts as a conduit for illegal fishermen into the KNP. The Letaba Ranch Nature Reserve rangers indicated no specific areas where fishing was prevalent and spatially defined the threat as present along the entire length of the two largest rivers flowing through the reserve. The discrepancy, between the MTRA results and extent of fishing, indicated on the threat maps implies that rangers either overestimated the reduction in this threat or have a poorer ability of spatially describing the threat.
Garbage and solid waste were recognised as a threat in both the LRNR and the Mahlangeni section of the KNP. It was identified as a threat to wildlife, which may get entangled in waste or die from consuming it. In the LRNR, garbage is being dumped across the fence into the LRNR (Figure 2a, b). The western part of the reserve is primarily (but not only) being affected, probably because the fence is more easily accessible from the road that runs along the border. Rangers try to collect as much garbage as they can during patrols, but this is not a priority. In Mahlangeni, solid waste is brought into the section by the Klein Letaba River from outside the park. During the dry season, when the management staff start eradicating IAS along the river, they also collect deposited garbage. Again, direct threats that originate from outside our study sites should be addressed by relevant authorities both within and outside the PAs.

Finally, in all three sites, rangers identified fire as crucial to the health of savanna ecosystems, as long as it is managed and controlled. However, (illegal) runaway fires were identified as a threat in both sections of the KNP. Possible causes of these uncontrolled fires could be fires lit in the rural and urban areas, as well as along the roads to the west of the study area, which can then spread to the east because of westerly winds in the spring, or fires lit by poachers.

\section{Additional management challenges}

The large increases for most threats found in the study suggest that management of both the buffer reserve and the studied sections of the KNP should be improved. Discussions with rangers and managers revealed that governance is a key problem in the LRNR, particularly in the northern MNR part. According to the strategic plan (LEDET 2013), that portion of the reserve should be managed jointly with the Mthimkhulu community and a co-management agreement was being drafted in 2013. However, during the MTRA workshop, it was clear that the LEDET management staff from the LRNR have a strong opinion that only they manage the entire area and made no mention of a co-management agreement or any sort of cooperation between the LEDET and the community. Interviews conducted with the community Chief and Mthimkhulu reserve manager suggest that the community is not benefitting from the reserve; hunting quotas are currently non-existent and they do not receive any other sort of compensation. The community also employs its own guards who supervise the north entrance to the reserve and conduct bike patrols. The fact that these stakeholders have a very different perception of the LRNR management constrains cohesion among managing institutions, increasing vulnerability to threats (as evidenced by negative MTRA index scores), and threatens the long-term resilience of both the LRNR and proximate sections of the KNP (Cumming et al. 2015). Poor governance seems to be the key reason why the LRNR does not function as an effective buffer, which has been demonstrated to inhibit conservation efforts both locally (Anthony, Scott \& Antypas 2010) and in a wider variety of contexts (Lockwood 2010). In our case, questions concerning good governance principles of 
legitimacy, inclusiveness and connectivity emerged which necessitate further investigation now that their impacts on managing threats to biodiversity have been elucidated.

It is clear that a more co-ordinated effort by diverse management institutions is needed in this buffer area which cannot be sidestepped if threat mitigation is to improve (Palomo et al. 2014). This is of particular importance if the KNP and the LEDET would like to enhance adaptive management as a key component of their overall management strategies (Gaylard \& Ferreira 2011).

\section{Advantages and limitations of the modified threat reduction assessment}

Our study confirmed some advantages of the tool, mentioned in earlier studies where TRA was applied (Anthony 2008): it is not time-consuming (no workshop lasted longer than $3 \mathrm{~h}$ ), does not require previously collected baseline data and enables all workshop participants' opinions to be taken into account, as the workshop moderator can facilitate the discussion and prevent individuals from dominating the discussion. In particular, the workshop setting allows for a more diversified group of participants, where rangers with different levels of experience and knowledge can contribute equally. In case of the MTRA, the added advantage of incorporating worsening and emerging threats into the assessment increases the accuracy and representativeness of the results, a point workshop participants also noted. We suggest that, where appropriate, the MTRA should be routinely utilised by PA management teams as a complementary MEE tool, integrating the geospatial exercise that can assist management teams in synthesising and communicating threat dynamics.

There are some disadvantages with the MTRA method, particularly subjectivity in measurements (Anthony 2008; Margoluis \& Salafsky 2001). For instance, the discrepancy between the MTRA results and the extent of fishing indicated on the threat maps implies that rangers either overestimated the reduction in this threat or have a poorer ability of spatially describing the threat. However, the high number of participants, although at times making the workshop execution more challenging, increased the objectivity and the validity of the results. Potential bias further originates from the susceptibility to memory loss (Papworth et al. 2009). Sending information about workshops beforehand, encouraging participants to bring supporting documentation about threats and choosing a shorter assessment period (5 years) were all strategies employed to minimise this bias (as suggested in Matar \& Anthony 2010).

Furthermore, when conducting TRAs, there is a risk of management staff overstating the threat reduction percentage in order to present their PA management as successful (Margoluis \& Salafsky 2001), especially if being compared to other PAs. Nonetheless, this problem was not evident in either of the PAs, as workshop participants were willing to assign high negative scores to certain threats, without considering the final TRA index, and were not informed about the intention to conduct workshops in other PAs. Finally, the MTRA tool does not explicitly reveal reasons for threat dynamics (e.g. a decrease in poaching because of decline in rhino numbers) and should be followed by a thorough discussion with management teams. Capturing these nuances and the multifaceted legal and illegal drivers of these threats under the larger threat category remains an important requirement in the MTRA methodology (Anthony 2008) and allows management teams to devise appropriate interventions to address these threats.

Spatially defining threats can be an extremely useful tool to incorporate into the MTRA as it allows enhanced analysis of the sources of identified threats in what Cumming et al. (2015) term the 'proximate institutional context' which, in our case, may extend beyond the LRNR and include other buffer areas of the KNP, and beyond. However, a caveat here is related to capacity. In some cases, rangers faced difficulties with spatially describing the threat suggesting either the need for more frequent training workshops or further restricting MTRA workshop participants to those competent in map reading.

Based on our experience, in addition to the strategies addressed in Matar and Anthony (2010), we recommend the following:

- When administering the tool, it is vital to ensure all participants' focus and engagement during the workshop. In our case, some individuals dominated the discussion and restricted full participation of other attendees.

- Depending on context, it is important to ensure a suitable number of workshop participants (6-8) and plan extra time for workshops, allowing for ample explanations, protracted discussions and/or reaching consensus.

- During the workshops, to enhance data validity, it is crucial to ensure that any supporting reference material is requested beforehand, accessible and consulted.

- In cases where multi-level governance structures are in place across PAs, a combined follow-up workshop may be useful to coordinate findings from individual sites, which can contribute to more strategic and collaborative threat mitigation efforts.

\section{Conclusion}

Through the administration of a MTRA tool, a number of threats to biodiversity were explicated in the LRNR and two neighbouring sections of the KNP, Mahlangeni and Phalaborwa. Although some of these threats were reduced, the overall MTRA indices of $-33.6 \%$ in the LRNR and $-14.67 \%$ in Phalaborwa indicate that total threats have worsened since the beginning of the assessment period in these two sites. In Mahlangeni, there was a reduction in threats of $13.2 \%$. Five of seven threats, spanning more than one assessment site and believed to be functionally related between the KNP and the LRNR, were discussed in this article. Threat mapping elucidated the probable facilitation of these threats between 
sites, for example, areas in which poaching incidents were recorded in the KNP are proximally prevalent in the portion of the assessed area which borders the LRNR and are likely facilitated by road networks.

Our key finding that the LRNR is currently not serving as an effective buffer to the KNP, manifested in a wide variety of threats and facilitating access to the KNP, may, in large part, be because of poor governance. Further research is required to delineate the drivers and nuances behind this finding, as well as explore other factors which emerged in our study and which may contribute to its relatively poor performance including lack of funding, socio-political factions and confusion over governance responsibilities (Cumming et al. 2015).

\section{Acknowledgements}

The authors would like to thank all workshop participants from the Letaba Ranch Nature Reserve and the Kruger National Park management teams. They also thank the journal editor and two anonymous reviewers for comments on an earlier draft of this article.

\section{Competing interests}

The authors declare that they have no financial or personal relationships that may have inappropriately influenced them in writing this article.

\section{Authors' contributions}

L.M. and B.P.A. designed the research. L.M. carried out the fieldwork and L.M., B.P.A. and A.S. analysed the data and wrote the article.

\section{Funding information}

This research was funded by the Central European University, Master Research Support Program.

\section{References}

Anderson, B., 2012, 'Assessing biodiversity threat mitigation efficacy: A case study of Kakum Conservation Area (2004 to 2012)', Master of Science thesis, Centra European University, Budapest.

Anthony, B.P., 2008, 'Use of modified threat reduction assessments to estimate success of conservation measures within and adjacent to Kruger National Park South Africa', Conservation Biology 22(6), 1497-1505. https://doi.org/10.1111/ j.1523-1739.2008.01030.x

Anthony, B.P., Scott, P. \& Antypas, A., 2010, 'Sitting on the fence? Policies and practices in managing human-wildlife conflict in Limpopo Province, South Africa', Conservation \& Society 8(3), 225-240. https://doi.org/10.4103/0972-4923.73812

Bengtsson, J., Angelstam, P., Elmqvist, T., Emanuelsson, U., Folke, C., Ihse, M. et al., 2003, 'Reserves, resilience and dynamic landscapes', Ambio 32(6), 389-396. https://doi.org/10.1579/0044-7447-32.6.389

Bertzky, B., Corrigan, C., Kemsey, J., Kenney, S., Ravilious, C., Besancon, C. et al., 2012, Protected Planet report 2012: Tracking progress towards global targets for protected areas, International Union for the Conservation of Nature (IUCN) and protected areas, International Union for the Conservation of Nature (IUCN) and
United Nations Environment Programme (UNEP)-World Conservation Monitoring United Nations Environment Programm
Centre (WCMC), Gland and Cambridge.

Chape, S., Harrison, J., Spalding, M. \& Lysenko, I., 2005, 'Measuring the extent and effectiveness of protected areas as an indicator for meeting global biodiversity
targets', Philosophical Transactions of the Royal Society A 360, 443-455. https:// targets', Philosophical Transactions
doi.org/10.1098/rstb.2004.1592

Coetzer, K.L., Erasmus, B.F.N., Witkowski, E.T.F. \& Reyers, B., 2013, 'The race for space: Tracking land-cover transformation in a socio-ecological landscape, South Africa', Environmental Management 52(3), 595-611. https://doi.org/10.1007/s00267013-0094-9
Convention on Biological Diversity (CBD), 2010, Conference of the Parties (COP) 10 Decision X/31. Protected Areas Section 19(a), viewed 20 June 2017, from http:// www.cbd.int/decision/cop/default.shtml?id=12297.

Craigie, I.D., Baillie, J.E.M., Balmford, A., Carbone, C., Collen, B., Green, R.E. et al., 2010, 'Large mammal population declines in Africa's protected areas', Biologica Conservation 143, 2221-2228. https://doi.org/10.1016/j.biocon.2010.06.007

Cumming, G.S. \& Allen, C.R., 2017, 'Protected areas as social-ecological systems: Perspectives from resilience and social-ecological systems theory', Ecological Applications 27(6), 1709-1717. https://doi.org/10.1002/eap.1584

Cumming, G.S., Allen, C.R., Ban, N.C., Biggs, D., Biggs, H.C., Cumming, D.H. et al., 2015 'Understanding protected area resilience: A multi-scale, social-ecological approach', Ecological Applications 25(2), 299-319. https://doi.org/10.1890/13-2113.1

Department of Environmental Affairs and Tourism (DEAT), 2009, National Biodiversity Framework, Department of Environmental Affairs and Tourism, Pretoria.

Driver, A., Sink, K.J., Nel, J.N., Holness, S., Van Niekerk, L., Daniels, F. et al., 2011, National biodiversity assessment 2011: An assessment of South Africa's National biodiversity assessment 2011: An assessment of South Africa's
biodiversity and ecosystems. Synthesis report, South African National Biodiversity biodiversity and ecosystems. Synthesis report, South African
Institute and Department of Environmental Affairs, Pretoria.

EMS Foundation, 2016, Enough is enough: How South Africa's policies are killing Africa's wild animals. A document prepared for CITES COP 2017, EMS Foundation, Africa's wild an
Honeydew.

Françoso, R.D., Brandão, R., Nogueira, C.C., Salmona, Y.B., Machado, R.B. \& Colli, G.R., 2015, 'Habitat loss and the effectiveness of protected areas in the Cerrado biodiversity hotspot', Natureza \& Conservação 13(1), 35-40. https://doi. org/10.1016/j.ncon.2015.04.001

Gaston, K.J. \& Spicer, J.I., 2004, Biodiversity: An introduction, 2nd edn., Blackwell, Oxford, UK.

Gaylard, A. \& Ferreira, S., 2011, 'Advances and challenges in the implementation of strategic adaptive management beyond the Kruger National Park - Making linkages between science and biodiversity management', Koedoe 53(2), Art. \#1005, 1-8. https://doi.org/10.4102/koedoe.v53i2.1005

Gertenbach, W.P.D., 1983, 'Landscapes of the Kruger National Park', Koedoe 26(1), 9-121. https://doi.org/10.4102/koedoe.v26i1.591

Hansen, A.J., Davis, C.R., Piekielek, N., Gross, J., Theobald, D.M., Goetz, S. et al., 2011 , 'Delineating the ecosystems containing protected areas for monitoring and management', Bioscience 61(5), 363-373. https://doi.org/10.1525/bio.2011. 61.5 .5

Hansen, A.J. \& DeFries, R., 2007, 'Ecological mechanisms linking protected areas to surrounding lands', Ecological Applications 17(4), 974-988. https://doi.org/ surrounding lands,

Hockings, M., 2003, 'Systems for assessing the effectiveness of management in protected areas', BioScience 53, 823-832. https://doi.org/10.1641/00063568(2003)053[0823:SFATEO]2.0.CO;2

Hockings, M. \& Phillips, A., 1999, 'How well are we doing? Some thoughts on the effectiveness of protected areas', Parks 9(2), 5-14.

International Union for the Conservation of Nature and Natural Resources (IUCN) World Commission on Protected Areas (WCPA), 2009, WCPA Strategic Plan 20052012, IUCN, Gland.

Laurance, W.F., Carolina Useche, D., Rendeiro, J., Kalka, M., Bradshaw, C.J.A., Sloan, S.P. et al., 2012, 'Averting biodiversity collapse in tropical forest protected areas', Nature 489(7415), 290-294. https://doi.org/10.1038/nature11318

Letaba Herald, 2015, 'Letaba Ranch: A nest of corruption', Letaba Herald, viewed 19 July 2018, from http://letabaherald.co.za/15823/letaba-ranch-a-nest-ofcorruption/.

Leverington, F., Costa, K.L., Courrau, J., Pavese, H., Nolte, C., Marr, M. et al., 2010, Management effectiveness evaluation in protected areas $-A$ global study, $2 \mathrm{nd}$ edn., The University of Queensland, Brisbane.

Limpopo Department of Economic Development, Environment and Tourism (LEDET), 2013, Five-year strategic plan for the Letaba Ranch Nature Reserve, Limpopo Province, South Africa, Limpopo Department of Economic Development, Environment and Tourism, Polokwane.

Lockwood, M., 2010, 'Good governance for terrestrial protected areas: A framework, principles and performance outcomes', Journal of Environmental Management 91, 754-766. https://doi.org/10.1016/j.jenvman.2009.10.005

Margoluis, R. \& Salafsky, N., 2001, Is out project succeeding? A guide to threat reduction assessment for conservation, Biodiversity Support Program, Washington D.C.

Matar, D. \& Anthony, B.P., 2010, 'Application of modified threat reduction assessments in Lebanon', Conservation Biology 24(5), 1174-1181. https://doi.org/10.1111/ j.1523-1739.2010.01575.x

McCallum, M.L., 2015, 'Vertebrate biodiversity losses point to a sixth mass extinction', Biodiversity and Conservation 24(10), 2.497-2519. https://doi.org/10.1007/ s10531-015-0940-6

Palomo, I., Montes, C., Martín-López, B., González, J.A., García-Llorente, M., Alcorlo, P. et al., 2014, 'Incorporating the social-ecological approach in protected areas in the Anthropocene', BioScience 64(3), 181-191. https://doi.org/10.1093/biosci/ bit033

Papworth, S.K., Rist, J., Coad, L. \& Milner-Gulland, E.J., 2009, 'Evidence for shifting baseline syndrome in conservation', Conservation Letters 2, 93-100. https://doi. org/10.1111/j.1755-263X.2009.00049.x

Pimm, S.L., Jenkins, C.N., Abell, R., Brooks, T.M., Gittleman, J.L., Joppa, L.N. et al., 2014, 'The biodiversity of species and their rates of extinction, distribution, and protection', Science 344(6187), 1246752. https://doi.org/10.1126/science. 1246752 
Ripple, W.J., Chapron, G., López-Bao, J.V., Durant, S.M., Macdonald, D.W., Lindsey, P.A et al., 2016, 'Saving the world's terrestrial megafauna', Bioscience 66, 807-812. et al., 2016, 'Saving the world's terres
https://doi.org/10.1093/biosci/biw092

Salafsky, N. \& Margoluis, R., 1999, 'Threat reduction assessment: A practical and costeffective approach to evaluating conservation and development projects', Conservation Biology 13, 830-841. https://doi.org/10.1046/j.1523-1739.1999.98183.x

Salafsky, N., Salzer, D., Stattersfield, A.J., Hilton-Taylor, C., Neugarten, R., Butchart S.H.M. et al., 2008, 'A standard lexicon for biodiversity conservation: Unified classifications of threats and actions', Conservation Biology 22(4), 897-911. https://doi.org/10.1111/j.1523-1739.2008.00937.x

South African National Parks (SANParks), 2018, Draft Kruger National Park Management Plan 2018-2028, South African National Parks, Skukuza.

Swemmer, L.K. \& Mmethi, A.H., 2016, Biodiversity for society - A reflection on the diversity of direct, local impacts (benefits and costs) of the Kruger National Park, South African National Parks, Muckleneuk, Pretoria.
Thomas, J.A., Telfer, M.G., Roy, D.B., Preston, C.D., Greenwood, J.J.D., Asher, J. et al. 2004, 'Comparative losses of British butterflies, birds, and plants and the global extinction crisis', Science 303(5665), 1879-1881. https://doi.org/10.1126/ science.1095046

Tucker, G., 2005, A review of biodiversity conservation performance measures, Earthwatch Institute, Oxford.

United Nations (UN), 2017, UN data: A world of information, viewed 03 July 2017, from http://data.un.org/CountryProfile.aspx?crName=south\%20africa.

United Nations Educational, Scientific and Cultural Organization (UNESCO), 1974, Task force on criteria and guidelines for the choice and establishment of biosphere reserves, MAB Report Series 22, UNESCO, Bonn.

United Nations Environment Programme's World Conservation Monitoring Centre (UNEP-WCMC) \& International Union for Conservation of Nature (IUCN), 2016, Protected planet report 2016, UNEP-WCMC and IUCN, Cambridge and Gland. 


\section{Appendix 1}

TABLE 1-A1: Modified threat reduction assessment index for the Letaba Ranch Nature Reserve.

\begin{tabular}{|c|c|c|c|c|c|c|c|c|}
\hline \multirow[t]{2}{*}{ No. } & \multirow[t]{2}{*}{ Threat } & \multirow[t]{2}{*}{ IUCN code } & \multicolumn{3}{|c|}{ Ranking criteria } & \multirow[t]{2}{*}{ Total ranking } & \multirow{2}{*}{$\begin{array}{c}\text { Percentage } \\
\text { mitigated }\end{array}$} & \multirow[t]{2}{*}{ Raw score } \\
\hline & & & Area & Intensity & Urgency & & & \\
\hline 1. & Hunting and collection of terrestrial animals & 5.1 & 10 & 10 & 7 & 27 & +5 & 1.35 \\
\hline 2. & Drought & 11.2 & 9 & 9 & 6 & 24 & -100 & -24 \\
\hline 3. & Fishing & 5.4 & 6 & 8 & 9 & 23 & 0 & 0 \\
\hline 4. & Invasive alien species & 8.1 & 7 & 6 & 8 & 21 & +50 & 10.5 \\
\hline 5. & Mining & 3.2 & 2 & 7 & 10 & 19 & -100 & -19 \\
\hline 6. & Dams & 7.2 & 5 & 5 & 3 & 13 & 0 & 0 \\
\hline 7. & Agricultural effluents & 9.3 & 4 & 4 & 5 & 13 & -70 & -9.1 \\
\hline 8. & Wood harvesting & 5.3 & 8 & 2 & 2 & 12 & +50 & 6 \\
\hline 9. & Problematic native species & 8.2 & 3 & 3 & 4 & 10 & -200 & -20 \\
\hline 10. & Garbage and solid waste & 9.4 & 1 & 1 & 1 & 3 & -40 & -1.2 \\
\hline Total & - & - & 55 & 55 & 55 & - & - & -55.45 \\
\hline
\end{tabular}

MTRA index: -33.6.

IUCN, International Union for the Conservation of Nature; MTRA, modified threat reduction assessment.

TABLE 2-A1: Threat reduction assessment index for Mahlangeni section of the Kruger National Park.

\begin{tabular}{|c|c|c|c|c|c|c|c|c|}
\hline \multirow[t]{2}{*}{ No. } & \multirow[t]{2}{*}{ Threat } & \multirow[t]{2}{*}{ IUCN code } & \multicolumn{3}{|c|}{ Ranking criteria } & \multirow[t]{2}{*}{ Total ranking } & \multirow{2}{*}{$\begin{array}{l}\text { Percentage } \\
\text { mitigated }\end{array}$} & \multirow[t]{2}{*}{ Raw score } \\
\hline & & & Area & Intensity & Urgency & & & \\
\hline 1. & Hunting and collection of terrestrial animals & 5.1 . & 7 & 7 & 7 & 21 & +49 & 10.29 \\
\hline 2. & Fishing & 5.4 & 6 & 6 & 5 & 17 & -50 & -8.5 \\
\hline 3. & Invasive alien species & 8.1 . & 4 & 4 & 6 & 14 & +70 & 9.8 \\
\hline 4. & Fire and fire suppression & 7.1 . & 5 & 5 & 4 & 14 & +30 & 4.2 \\
\hline 5. & Mining & 3.2 . & 3 & 2 & 3 & 8 & -50 & -4 \\
\hline 6. & Garbage and solid waste & 9.4 & 2 & 3 & 2 & 7 & -10 & -0.7 \\
\hline 7. & Utility and service lines & 4.2. & 1 & 1 & 1 & 3 & 0 & 0 \\
\hline Total & - & - & 28 & 28 & 28 & - & - & 11.09 \\
\hline
\end{tabular}

MTRA index: 13.2.

IUCN, International Union for the Conservation of Nature; MTRA, modified threat reduction assessment.

TABLE 3-A1: Threat reduction assessment index for Phalaborwa section of the Kruger National Park.

\begin{tabular}{|c|c|c|c|c|c|c|c|c|}
\hline \multirow[t]{2}{*}{ No. } & \multirow[t]{2}{*}{ Threat } & \multirow[t]{2}{*}{ IUCN code } & \multicolumn{3}{|c|}{ Ranking criteria } & \multirow[t]{2}{*}{ Total ranking } & \multirow{2}{*}{$\begin{array}{l}\text { Percentage } \\
\text { mitigated }\end{array}$} & \multirow[t]{2}{*}{ Raw score } \\
\hline & & & Area & Intensity & Urgency & & & \\
\hline 1. & Hunting and collection of terrestrial animals & 5.1. & 5 & 5 & 5 & 15 & +60 & 9 \\
\hline 2. & Invasive alien species & 8.1. & 4 & 3 & 4 & 11 & -200 & -22 \\
\hline 3. & Fire and fire suppression & 7.1. & 1 & 4 & 3 & 8 & +80 & 6.4 \\
\hline 4. & Utility and service lines & 4.2. & 2 & 2 & 2 & 6 & 0 & 0 \\
\hline 5. & Air pollution & 9.5. & 3 & 1 & 1 & 5 & 0 & 0 \\
\hline Total & - & - & 15 & 15 & 15 & - & - & -6.6 \\
\hline
\end{tabular}

MTRA index: -14.67.

IUCN, International Union for the Conservation of Nature; MTRA, modified threat reduction assessment. 